streamlet in the wide wide world which is not at this moment a boulder-factory. Take Europe ; in Scotland, Switzerland, and Norway you may see the whole of the hill-side streaked with streams of boulders. They are hurled into Romsdal now by every cascading river and rivulet or dry gullet which scores its magnificent mountain sides when flooded by rain or its equivalent melted snow. Every cascade of water above forms a cascade of boulders below ending in a somewhat vertical triangle or delta of boulder talus. That is, these triangles or deltas of boulders are horizontal where there is room, while they approach the vertical directly as the narrowness of the valley and the consequent steepness of its sides.

Distinct from the clays resulting from atmospheric disintegration, this inland grinding of rock into boulders and pebbles is the main source of the sand which is found mingled with boulders in the parallel terraces into which raised marine alluvial plains are cut, and of the intand parallel terraces on the opposite sides of each soft valley above each hard gorge. It is the source of the sand of the Scottish Kames and of the Irish Eskers. The socalled northern drift and glacial drift are the combined result of almospheric decomposition and marine and inland grinding of rock, sized and sorted by water.

This is all going on now, as it ever has gone on qualis ab incepto and according to the fortuna locorum. That is according to the circumstances of the place, not the period. And nothing can be more absurd than the expression a "drift period" or a "boulder period" or a "pluvial period" or a "diluvial period" or a "gravel period " or a "period of invertebrates" or an "age of reptiles," or other mistakes between place and period.

Brookwood Park, Alresford, Sept. 14, I872 GEORGe GreEnwoOD

P.S.-Since this was written, I have had the honour to receive from the Smithsonian Institution the Report of the Survey of Wyoming, by Mr. Hayden, United States Geologist.

As far as I have read, he appears to attribute the moulding of the earth's surface, after upheaval, not to 'glacial but to atmospheric agency and the erosion of rivers. With regard to the inland grinding of rock into boulders, pebbles, and sand, he describes, page 14, the "worn masses of iron ore" "in the bed of the Chugwater," and ends thus: "thousands of tons have been washed ciown to the valley of the Chug and distributed among the superficial drift. As we leave the ore beds themselves, these strong masses are larger and more angular, and as we pass down the Chug they dwindle to minute pebbles and disappear."

\section{An Entomological Query}

I FIND the subjoined note in the recently-published " $3^{\mathrm{e}}$ Livraison of Fauvel's Faune Gallo-rhénane; Colćoptères, p. II. Will some entomologist kindly say whether Fauvel's observation has been since verified or not? If correct, it is one of the most curious of the many curious phenomena connected with beetle-life in formicaries.

"J'ai remarquè ailleurs (Bull. Soc. Linn. Norm. 1861, v. 252), que, sur un assez grand nombre d'individus capturés dans les fourmillières, il ne se trouvait pas un seul $\delta$. J'engage les entomologistes à vérifier ce fait, si l'occasion s'en présente. Il peut avoir de l'importance au point de vue des mours peu connues de nos espèces myrmécophiles."

The note has specia! reference to Micropcplus stapliylinoides.

Itchen Abbas, Alresford, September 28

W. W. SPICER

\section{Cats' 'Teeth}

DouBTLESs the case mentioned by Mr. Lydekker is somewhat unusual; but the mere fact of an animal possessing an extra tooth can hardly upset Prof. Owen's theory. It is by no means an uncommon thing to meet with examples of supernumerary teeth in man, and these rarely disturb the arrangement of the others, (mostly occurring on the palatal or lingual sides of normal teeth), I do not therefore see why (judging from analogy) it should be very unusual for the lower animals to possess like peculiarities, although they are not often met with on account of the limited number of skulls examined. Mr. L. does not tell us whether the extra tooth occurs in the superior or inferior maxilla.
4, Finsbury Square
W. G. RANGER

\section{PHOSPHORESCENCE IN FISH}

W

HILE off the Land's End, Cornwall, or between the "Wolf Rock" and "Longships" Lighthouses, in the screw steam-ship Cumbrae (ex Plymouth for Belfast and Glasgow), on the night of Thursday, August 27, my attention was directed to one of the most beautiful marine phenomena that could weil be imagined. At some distance ahead of the vessel the sea appeared quite luminous over large portions of its surface. This luminosity, observed at intervals, on a nearer approach proved to be nothing more nor less than the phosphorescence of immense shoals of fish-mackerel or pilchards, probably both-which could be distinctly seen near the surface; they of course appeared somewhat large, owing to the light which they emitted.

It was a dark, rough night, a strong breeze blowing off the Atlantic at the time; and as a consequence, the vessel, as may be supposed from her description, was lurching and pitching considerably -in fact more so than I had ever experienced in any other vessel, or on any previous occasion.

Having taken up a position on the forecastle, and secured myself by a tight hold on the stanchions immediately over the bow, I watched these fish with intense interest-so much so that at times I could scarcely restrain myself from a loud burst of laughter, so exceedingly interesting were their movements. As the vessel rolled and dipped, these fish, evidently startled by her movements, could be seen near the surface, ahead and on the starboard and port bow, darting forward in quantities as close as I should think it was possible they could well swim together. It was a sight long to be remembered.

I may add, that as the sea broke over the fore part of the vessel, the spray rested on me in drops or globules of, as it were, fatty matter, and much resembled in its luminosity, which lasted for some time, the appearance of so many glow-worms; doubtiess this was given off by the fish themselves.

Sorne interesting particulars of the nature of phosphorescence in fish appeared in NATURE (Notes) vol. iv. p. 287 (Aug. 10, 1871), as presented in a memoir to the Association of Naturalists and Physicians at Turin, by Sig. Panceri of Naples, from which I extract the following :-

"The phosphorescent substance in fishes, in whatever part of the body it may be situated, is always fat" (this bears out my former remarks) "and the phenomenon is due to its slow oxidation in contact with air."

Further particulars appeared in NATURE, vol. v. p. I 32 (Notes), December $14,187 \mathrm{I}$, as derived from the same author, of which the following is also an extract :-

"In all cases the phosphorescence is due to matter cast off by the animal-it is a property of dead separated matter, not of the living tissues.

"He" (Sig. Panceri) "also finds that this matter is secreted by glands, possibly special for this purpose, but more probably the phosphorescence is a secondary property of the secretion. Further, the secretion contains epithelial cells in a state of fatty degeneration, and it is these fatty cells and the fat which they give rise to which are phosphorescent. It is due to the formation in decomposition of a phosphoric hydro-carbon, or possibly of phosphuretted hydrogen itself."

Are there any special conditions of weather, or season, during which this phenomenon of phosphorescence is more readily observed than at others? Although by no means a stranger to the sea, I have never, on any occasion, seen anything approaching to it.

I made a trip from Plymouth to the Eddystone Lighthouse and back on the previous night, and although nets were out (as known by their floats) at some distance from land for the purpose of securing the fish that I have mentioned, no phosphorescence of the kind was to be seen; the sea on this occasion was comparatively smooth. JOHN JAMES HALL 